\title{
Development of Manually Operated Single Row Oil Seed Drill
}

\author{
C. Naveen Kumar*, M. Murali and A. R. Radha Krishna \\ College of Agricultural Engineering, Gandhi Krishi Vigyan Kendra, University of \\ Agricultural Sciences, Bengaluru- 560064, Karnataka, India \\ *Corresponding author
}

A B S T R A C T

\section{Keywords}

Soil, Mechanization, Sowing, Seed and Seed drill

Article Info

Accepted:

20 November 2019

Available Online:

10 December 2019
Sowing of seeds with seed drill at proper seed rate, depth and covering them with soil is very important. This allows plants to get sufficient sunlight and nutrients from the soil and also saves them from being eaten by birds or being dried up due to exposure to sun. Meanwhile it ensures improved ratio of crop yield with saving in time and labour. Small land holding in Indian farms limits farm mechanization on Indian farms. Conventional methods of seeding will results in low seed placements, less area covered per unit time, physical health issue like back ache etc. Keeping all in view a manually operated seed drill for mustard seeds was developed specially for small and marginal farmers with 1-1.5 kg seed box capacity and seed drill weight of $9-10 \mathrm{~kg}$. The developed seed drill is useful for the small and marginal farmers who cannot afford heavy machinery.

\section{Introduction}

In India total area under cultivation is 329 million hectares, Where most of the farmers having small and marginal land holdings. The most challenge and most pressing need for the professional agricultural engineers is to identify appropriate mechanization needs of different size of land holdings located in different agro climatic regions and socio economics strata of the country. It is misconceived that benefits of mechanization could be reaped only by farmers having large acreage (Ananymous, 2008). Equipments for tillage, sowing, irrigation, plant protection and threshing have widely been accepted by them. Even farmers with small holdings utilize selected improved farm equipment through custom hiring to increase productivity and reduce cost of production.

Mustard (Brassica sp.) is a well known condiment and an important oil seed crop of the family Cruciferae. The plant is also used as a vegetable, fodder and medicine. Seed production can be done in Rabi (from September and October) in plains and in hills during kharif (June - July) (Ananymous, 2009). Next to food grains in terms of hectare, production and value, oilseeds play a vital role. India accounts for about 13 per cent of world's oilseed area, 7 per cent of world's oilseeds output and 10per cent of world's edible oils consumption (Jha et al., 2012). Manual sowing has the problem of not giving adequate spacing between row to row and 
plant to plant leading to less population of crops than recommended by the agronomists. Also there is the problem of placing the seeds at correct depth and correct soil coverage. Manual sowing is time consuming requires about 20 to 30 man-hours per ha of land, and that takes away about 8per cent of total manhours in farming and costly. Hence, there is a need for appropriate seed drill for sowing (Kiran and Dathwade, 2016). Seed drill is a machine for placing the seeds in a continuous flow in furrows at uniform rate and at controlled depth with or without the arrangement of covering them with soil (Ananymous, 2010). It is manually operated implement suitable for sowing rapeseed/ mustard (millets) by changing the size of the circular opening in hopper bottom, other crops like wheat, green gram can also be sown, it is also suitable for inter row sowing. Line sowing not only saves seed but also allows post sowing operations conveniently and efficiently. Besides, it helps control of weeds through use of mechanical weeders. Therefore the present study has planned to develop manually operated seed drill for oil seeds with covering mechanism.

\section{Materials and Methods}

A study on development of manually operated inter row seed drill for oil seed was taken up in the Department of Agricultural Engineering, University of Agriculture Sciences, Gandhi Krishi Vignana Kendra, Bangalore during 2012-13. The design procedure and methodology is given below.

\section{Size of seed drill}

The size of the seed cum fertilizer drill was calculated by following equation (Sharma and Mukesh, 2013).

$\mathrm{Z}=\mathrm{D} / \mathrm{d}$

Where,
$Z=$ Number of furrow openers in the drill

$\mathrm{D}=$ Draft of drill, kgf

$\mathrm{d}=$ Draft of each row, $\mathrm{kgf}$

\section{Working width of machine}

$\mathrm{W}=\mathrm{Z} / \mathrm{a}$

Where,

$\mathrm{W}=$ Working width of machine, $\mathrm{cm}$

$\mathrm{Z}=$ Number of furrow openers in the drill

$\mathrm{a}=$ row to row distance, $\mathrm{cm}$

\section{Design of seed box}

Trapezoidal shape of seed boxes is generally used in the machine for free flow of seed in hopper bottoms (Sharma and Mukesh, 2013).

\section{Volume of seed box}

$\mathrm{V}_{\mathrm{b}}=1.1 \mathrm{~V}_{\mathrm{S}}$

$\mathrm{V}_{\mathrm{S}}=\mathrm{W}_{\mathrm{s}} / \gamma_{\mathrm{s}}$

$\mathrm{V}_{\mathrm{b}}=1.1 \mathrm{~W}_{\mathrm{s}} / \gamma_{\mathrm{s}}$

Where,

$\mathrm{V}_{\mathrm{b}}=$ volume of seed box, $\mathrm{cm}^{3}$

$\mathrm{V}_{\mathrm{S}}=$ volume of seed, $\mathrm{cm}^{3}$

$\mathrm{W}_{\mathrm{s}}=$ weight of seed in the box, $\mathrm{g}$

$\gamma_{\mathrm{s}}=$ bulk density of seed, $\mathrm{g} / \mathrm{cm}^{3}$

\section{Design of seed metering mechanism}

\section{Adjustable orifice with agitator}

In the developed seed drill, seed flow was regulated by changing the size of opening provided at hopper bottom. An agitator fixed above seed opening helps in continuous flow of seeds (Sharma and Mukesh, 2013).

\section{Circular openings(d)}

$\mathrm{D}=2 \mathrm{P} / \rho_{\mathrm{s}} \sin 2 \alpha$ 
Where,

$\mathrm{P}=$ confined yield strength of material, $\mathrm{kg}$

$\rho_{\mathrm{s}}=$ specific weight of seed, $\mathrm{kg} / \mathrm{m}^{3}$

$\alpha=45^{0}-\varphi / 2$, inclination angle of pouring planes

$\varphi=$ internal friction of seed, degrees

The flow rate of seed through circular orifice/ opening is given by

$\mathrm{Q}=\mathrm{F} \times \rho_{\mathrm{s}} \times \mathrm{A}_{0}\left(2 \mathrm{~g} \times \mathrm{P} / \rho_{\mathrm{s}}\right)^{0.5}$

Where,

$\mathrm{Q}=$ Flow rate of seeds, $\mathrm{g} / \mathrm{s}$

$\mathrm{F}=$ Flow rate index depends on geometry of seed box and opening

$\rho_{\mathrm{s}}=$ Bulk density of seeds pouring out of orifice, $\mathrm{g} / \mathrm{cm}^{3}$

$\mathrm{A}_{0}=$ Area of orifice, $\mathrm{cm}$

$\mathrm{g}=$ Acceleration due to gravity, $\mathrm{g} / \mathrm{s}^{2}$

$\mathrm{P}=$ Static pressure of seed mass, $\mathrm{g} / \mathrm{cm}^{2}$

\section{Power transmission system design}

A standard roller chain with $15 \mathrm{~mm}$ pitch commonly used in cycles was selected for transmission of power (Sharma and Mukesh, 2013).

The chain length was calculated by following equation

$\mathrm{m}=2 \mathrm{C} / \mathrm{p}+\left(\mathrm{Z}_{1}+\mathrm{Z}_{2}\right) / 2+\left(\mathrm{Z}_{2}-\mathrm{Z}_{1}\right)^{2} / 2 \Pi \mathrm{p}$

Where,

$\mathrm{m}=$ number of chain links

$\mathrm{C}=$ center to center distance between two

sprocket, $\mathrm{mm}$

$Z_{1}=$ number of teeth in driver pulley

$Z_{2}=$ number of teeth in driven pulley

$\mathrm{P}=$ chain pitch, $\mathrm{mm}$

\section{Design of handle}

It is the integral part of the frame which is used to move or pull the implement for its operation. While designing handle an average standing elbow height of women workers was considered (Sharma and Mukesh, 2013).

\section{Results and Discussion}

\section{Design of components}

\section{Ground wheel}

Ground wheel is the main supporting structure for the other components of the implement on which they are mounted. It is provided to drive the metering rolls. It is fabricated using 1.5 inch width, 0.25 inch thickness MS flat of $1318.8 \mathrm{~mm}$ to form a wheel of diameter $420 \mathrm{~mm}$.the flat is heated and then beaten to get it to the desired round shaped and later welded at joint.

A spoke is one of the components of ground wheel where some number of rods radiating from the center of a wheel connecting the hub with the round traction surface. There are 6 spokes in the wheel to provide a proper support to the weight. Here we used the spokes of $190 \mathrm{~mm}$ length each. Lugs are the small piece of round iron rod, which is welded outer surface of wheel to provide a proper traction on the wet field or ground 23 lugs of $20 \mathrm{~mm}$ length each is used and welded externally on wheel flat.

\section{Bush}

A 2 inch thickness MS rod of length 5 inch for the fabrication of bush. $2 \mathrm{~cm}$ diameter hole was drilled to place $2 \mathrm{~cm}$ diameter MS rod for the easy rotation. MS rod externally turned using to suit the internal diameter of the chain sprocket in order to facilitate the easy rotation. 


\section{Shaft}

The shaft is a rotating member having circular cross section to which transmitting elements such as pulleys, belt, gears and other rolling element bearings are mounted. The material used for shaft was high carbon iron rod of grade $40 \mathrm{C} 8$, ultimate strength of $560-670 \mathrm{MPa}$ and yield strength of $320 \mathrm{MPa}$. Standard size shaft of $15 \mathrm{~mm}$ diameter was selected keeping a factor of safety about 4 .

\section{Wheel frame}

1.5 inch width MS flat having thickness 0.25 inch was used for the fabrication of frame.
Total length of MS flat is 32 inch \& at each ends of frame small hole was drilled to place the bush rod.

\section{Power transmission system}

Developed seed drill was designed to operate agitator shaft by taking power from ground wheel with chain and sprocket arrangement. 20 teeth 2 sprockets of same size of 3.5 inch diameters were used in the fabrication of seed drill. A standard roller chain with $15 \mathrm{~mm}$ pitch commonly used in cycles was selected for transmission of power (Fig. 1 and Table $1)$.

Table.1 Specification of the developed seed drill

\begin{tabular}{|c|c|c|c|}
\hline S. No. & Parameter & Specifications & Material \\
\hline 1 & Length & $160 \mathrm{~cm}$ & \\
\hline 2 & Height & $100 \mathrm{~cm}$ & \\
\hline 3 & Width & $60 \mathrm{~cm}$ & \\
\hline 4 & Furrow opener & Sweep type furrow opener & High carbon steel \\
\hline 5 & $\begin{array}{l}\text { Seed metering } \\
\text { mechanism }\end{array}$ & $\begin{array}{l}\text { Gravity seed metering device } \\
\text { with adjustable orifice with } \\
\text { agitator }\end{array}$ & $\begin{array}{c}\text { Helical rubber roller } \\
\text { on agitator shaft }\end{array}$ \\
\hline 6 & Ground wheel & $\begin{array}{c}1.5 \text { inch width, } 0.25 \text { inch } \\
\text { thickness, wheel diameter } \\
420 \mathrm{~mm}\end{array}$ & MS flat \\
\hline 7 & Seed hopper & $\begin{array}{l}\text { Top }=150 \times 100 \mathrm{~mm} \\
\text { Bottom }=25 \times 100 \mathrm{~mm}\end{array}$ & 18 gauge MS sheet \\
\hline 8 & Seed tube & 16 inch length, 1 inch diameter & Plastic hose pipe \\
\hline 9 & Power transmission & Chain and sprocket & \\
\hline 10 & Transmission ratio & $1: 1$ & \\
\hline 11 & Weight & $9.16 \mathrm{~kg}$ & \\
\hline
\end{tabular}


Fig.1 Developed seed drill

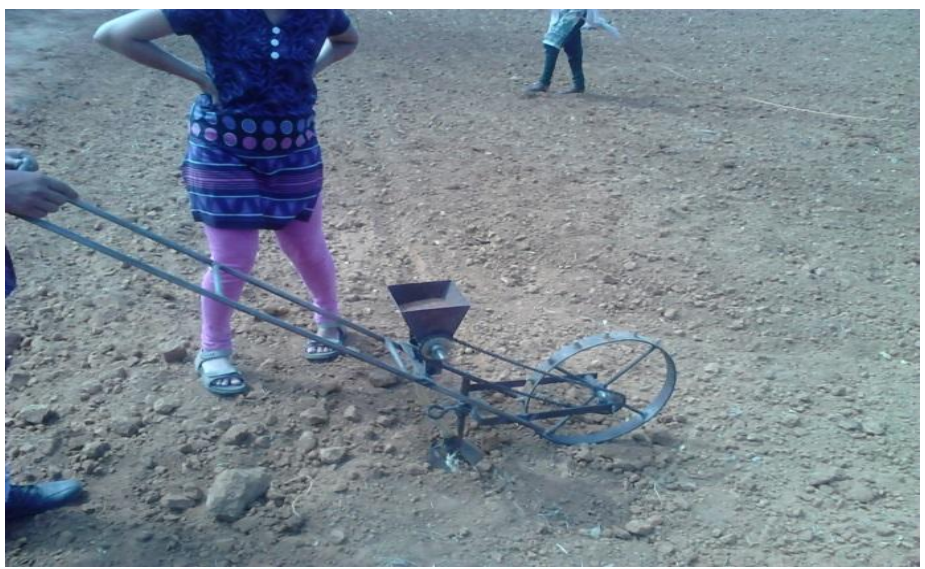

\section{Furrow opener}

12 gauge MS sheet was used for fabrication of furrow opener and 0.75 inch MS square rod also used for furrow opener. Furrow opening width is 5 inch $\&$ furrow covering mechanism also provided at the back side of furrow opener using 18 gauge MS sheet of width 6 inch.

\section{Square clamp}

Square clamp has made by using angle iron of 0.25 inch thickness. it helps to adjust height of furrow opener according to requirement.

\section{Seed box}

Seed box was made by using 18 gauge MS sheet. Seed box capacity is $1-1.5 \mathrm{~kg}$. $2 \mathrm{~mm}$ hole has been drilled at bottom of the seed box using drilling machine for the easy flow of seeds.

Top $=150 \times 100 \mathrm{~mm}$

Bottom $=25 \times 100 \mathrm{~mm}$

\section{Funel}

Funnel is made by using 18 gauge MS sheet. Its width of opening is 3 inches. Total length of funnel is 5 inch.

\section{Handle and beam}

A standard light weight of 18 gauge MS Conduit pipe of $3 / 4$ inch, $1750 \mathrm{~mm}$ length was used for handle of seed drill. Length of handle was calculated based on average standing elbow height of female operator's i.e. $100 \mathrm{~cm}$. Each ends of handle beam is flattened for length 3 inch using hammer. These handle beam and wheel frames are joined by spit pin by drilling hole at the both ends of handle beam.

\section{Covering mechanism}

The covering mechanism was used to cover and compact the soil over seeds in the furrows. 18 gauge thick metal sheet of 6 inch in width was used for its construction.

In conclusion, the study revealed that width of furrow open by seed drill was $12.5 \mathrm{~cm}$ and depth is easily adjustable. Field should be properly prepared and there should be optimum moisture content of soil to operate the seed drill more efficiently and with less human drudgery.

The cost of the developed seed drill was found to be 2250 rupees. Developed seed drill was best suitable for small and marginal farmers. 


\section{References}

Chaudhuri, D. 2001. Performance evaluation of various types of furrow openers on seed drills. Journal of Agricultural Engineering Research, 79: 125-137.

Ess, D. R., Hawkins, S. E., Young, J. C. and Christmas, E. P. 2005. Evaluation of the performance of a belt metering system for soybeans planted with a grain drill. Applied Engineering in Agriculture, 21: 965-969.

Haque E. M., Meisner C. A., Hossain I., Justice C., Sayre K. 2004. Two-Wheel Tractor Operated Seed Drill: A Viable Crop Establishment and Resource Conservation Option. Proc.Int. Conf. Beijing Sponsored by CIGR, CSAM and CSAE Beijing, China 11- 14 October 2004.

Heege, H. J. 1993. Seeding methods performance for cereals, rape, and beans. Transaction of ASAE. 36: 653661.

http://ecoursesonline.iasri.res.in/mod/page/vie w.php?id=2787, 2008

http://www.hillagric.ac.in/edu/coa/agengg/lect ure/243/Lecture $\% 2013 \% 20$ Sowing\%20 equipment.pdf, 2010
https://kvk.icar.gov.in/API/Content/PPupload/ k0561_32.pdf, 2009

Janelle, L., Lague, C. and Tessier, S. 1993. Seeding tool design for no tillage conditions in North-East. ASAE Paper No. 93-1561. St. Joseph, MI: ASAE.

Jha, G. K., Pal, S., Mathur, V.C., Bisaria, G., Anbukkani, P., Burman, R.R. and Dubey, S.K. 2012. Edible Oilseeds Supply and Demand Scenario in India: Implications for Policy, Indian Agricultural Research Institute.

Karayel, D., Wiesehoff, M., Ozmerzi, A. and Muller, J. 2006. Laboratory measurement of seed drill, seed spacing and velocity of fall of seed using highspeed camera system. Computers and Electronics in Agriculture. 50: 89-96.

Kiran, A.S. and Dathwade, B. P. 2016, Design and Fabrication of Automatic Seed Sowing Machine with Variable Pitch. European Journal of Advances in Engineering and Technology, 3: 50-54.

Sharma, D.N. and Mukesh, S. 2013. Farm Machinery Design Principles and Problems. Jain Brothers, New Delhi, 131-157.

\section{How to cite this article:}

Naveen Kumar, C., M. Murali and Radha Krishna, A. R. 2019. Development of Manually Operated Single Row Oil Seed Drill. Int.J.Curr.Microbiol.App.Sci. 8(12): 2683-2688. doi: https://doi.org/10.20546/ijcmas.2019.812.314 